\title{
子宮癌術後排尿障害に対する尿流動態学的検討
}

\author{
愛媛大学泌尿器科学教室（主任：竹内正文教授） \\ 飯尾 昭三 吉岡 進 西尾 俊治 \\ 横山 雅好岩田 英信 竹内 正文

\section{URODYNAMIC EVALUATION FOR BLADDER DYSFUNCTION AFTER RADICAL HYSTERECTOMY} \\ Shouzo Iio, Susumu Yoshioka, Syunji Nishio, Masayoshi Yokoyama, \\ Hidenobu Iwata and Masafumi Takeuchi \\ Department of Urology, Ehime University School of Medicine \\ (Director: Prof. Masafumi Takeuchi)
}

Bladder dysfunction after radical hysterectomy and/or radiotherapy for uterine cancer is a serious problem. Its pathogenesis has not been well elucidated. Urodynamic and clinical evaluations were performed in 53 patients; 24 of them underwent radical hysterectomy and postoperative radiotherapy $(\mathrm{RH}+\mathrm{RT}), 13$ had radical hysterectomy alone $(\mathrm{RH}), 7$ had modified radical hysterectomy $(\mathrm{mRH}), 9$ had radiotherapy alone (RT). Nine preoperative patients without micturition disturbance were examined, serving as controls. Patients with more than $50 \mathrm{ml}$ of residual urine were only 3 in $\mathrm{RH}+\mathrm{RT}, 2$ in $\mathrm{RH}$ and 1 in RT. Bladder volumes at maximum desire to void were significantly lower in RT than in controls. Intravesical pressures at maximum desire to void were significantly higher in $\mathrm{RH}+\mathrm{RT}$ and $\mathrm{RH}$ than in controls, but there were no significant differences between $\mathrm{mRH}$ or RT and controls. Detrusor compliances significantly decreased after radical hysterectomy and/or radiotherapy. Maximum urethral closure pressures significantly decreased after radical hysterectomy with or without radiotherapy. In RH + RT, 18 patients $(75 \%)$ of them mainly complained of urinary incontinence. Their functional profile lengths were significantly shorter than in controls. We conclude that the pelvic plexus injury by radical hysterectomy compromise both urethral closure function and bladder compliance.

Key words: uterine cancer, neurogenic bladder, urodynamic study

\footnotetext{
要旨：子宮癌根治術及び放射線療法の膀胱尿道機能に対する影響について尿流動態学的検討を行った. 対象は子宮癌根治術及び放射線療法後の患者 53 例で，広汎子宮全摘術＋放射線療法（RH+RT）24例， 広汎子宮全摘術（RH）13例，準広沉子宮全摘術（mRH） 7 例，放射線単独療法（RT） 9 例であった。 根治術前及び排尿障害のない婦人科患者 9 例を対照とした。 $50 \mathrm{ml}$ 以上の残尿を有する症例は RH+RT 群で 3 例, RH 群で 2 例, RT 群で 1 例であった。最大尿意時膀脱容量は RT 群では平均 $203 \mathrm{ml}$ と有意に 減少しており, RH+RT 群でもやや減少していた。 $\mathrm{RH}$ 群, $\mathrm{mRH}$ 群では対照群と比較し差がなかった。 最大尿意時膀胱内圧は $\mathrm{RH}+\mathrm{RT}$ 群及び $\mathrm{RH}$ 群では有意に上昇していたが, $\mathrm{mRH}$ 群, $\mathrm{RT}$ 群では差がな かった。排尿筋コンプライアンスは RH+RT 群, $\mathrm{RH}$ 群， RT 群では有意に低下していた。最大尿道閉 鎖圧は RH+RT 群, RH 群では有意に低下しており, mRT 群, RT 群では対照群と比較して差がなかっ た。機能的尿道長は対照群では平均 $3.3 \mathrm{~cm}$ であったが, $\mathrm{RH}+\mathrm{RT}$ 群では平均 $2.4 \mathrm{~cm}$ と有意に短縮し, $\mathrm{RH}+\mathrm{RT}$ 群のらち18例（75\%) は尿失禁を主訴としていた。宮癌根治術による骨盤神経叢損傷は排尿 筋過活動による排尿筋コンプライアンスの低下及び尿道括約機能の低下をきたするのと考兄られた。 キーワード : 子宮癌, 神経因性膀胱, 尿流動態検査
} 


\section{緒言}

子宮癌根治術及び放射線療法により膀胼尿管損傷, 尿管狭窄, 神経因性膀胱など多くの泌尿器科的合併症 が起こりらることが知られている。特に広汎子宮全摘 術は子宮頸癌に対し広く用いられ，良好な臨床成績が 得られているが, リンパ節廓清に伴う骨盤神経叢損傷 による神経因性膀胱は術後長期間にわたり患者の Quality of life を低下させる一因となっている. 従来 子宮癌根治術後の排尿障害については半ば当然である といら認識が医師，患者の双方に存在し，重篤な尿路 合併症をさたし初めて泌尿器科受診することも多く見 られた。しかし最近，患者のQuality of life 及び尿失 禁に対する注目が高をるにつれ，排尿障害で受診する 患者が増加してきており, 子宮癌根治術後の膀胼尿道 機能障害に対する正確な評価が重要と考えられてい る．子宮癌根治術による神経因性膀胼について多くの 研究がなされているが，施設及び患者により手術法や 術後の排尿管理法等が異なることより，様々の報告が なされている ${ }^{1) 44}$ 。また高率に併用される放射線療法 による影響についても不明な点が多い5). 今回我々は 子宮癌根治術及び放射線療法の膀胼尿道機能に対する 影響について尿流動態学的検討を行い評価を試みたの で報告する。

\section{対象及び方法}

対象は1989年より 1991年の 3 年間に愛瑗大学泌尿器 科を受診し，尿流動態検査を施行できた子宮癌根治術 及び放射線療法後の患者 53 例で，広沉子宮全摘術十放 射線療法 (RH+RT) 24例，広汎子宮全摘術 $(\mathrm{RH}) 13$ 例，準広汎子宮全摘術（mRH）7 例，放射線単独療法

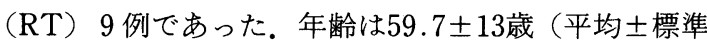
偏差), 子宮癌治療後の平均経過期間は63.9力月であっ た。対照として根治術前及び排尿障害のない婦人科良 性疾患の患者 9 例, 年齢 $57 \pm 15$ 歳についても尿流動態 検査を施行し検討を行った（Table 1).

尿流動態検査はDANTEC 社製 URODYN-5000を 使用した。患者にトイレにて排尿させた後，仰卧位に て富士システムズ社製 UPP カテーテル（8Fr，4 孔） を挿入し残尿測定した後, 膀胼内圧測定を行った. 膀 胼内への炭酸ガス注入速度は $50 \mathrm{ml} / \mathrm{min}$ で測定し，尿 意の減弱した患者においては最大腹満時またはカテー テル周囲より炭酸ガスの漏れが出現した時点を最大尿 意時とした。尿道内圧測定は膀胱内を空虚にした後, 膀胱内圧測定に用いた UPP カテーテルを使用し，炭 酸ガス注入速度 $50 \mathrm{ml} / \mathrm{min}$ ，カテーテル引き抜き速度 2
Table 1 Patient characteristics

\begin{tabular}{lcc}
\hline \multicolumn{1}{c}{ Prior therapy for uterine cancer } & No. of Pts. & Mean age \pm SD \\
\hline $\begin{array}{l}\text { Radical hysterectomy } \\
\text { with postoperative radiotherapy }\end{array}$ & 24 & $60 \pm 11$ \\
Radical hysterectomy & 13 & $54 \pm 14$ \\
Modified radical hysterectomy & 7 & $56 \pm 14$ \\
Radiotherapy alone & 9 & $70 \pm 9$ \\
Control & 9 & $57 \pm 15$ \\
\hline
\end{tabular}

$\mathrm{mm} / \mathrm{sec}$ で測定した。またこれらの検査とは異なった 日に $\mathrm{RH}$ 群の 3 例, $\mathrm{RH}+\mathrm{RT}$ 群の 6 例, $\mathrm{mRH}$ 群の 3 例に対し URODYN-1000を使用し尿流量測定を行っ た。

以上の方法で測定した最大尿意時膀胱容量 $\left(\mathrm{V}_{\mathrm{MDV}}\right)$, 最大尿意時膀胱内圧 $\left(\mathrm{P}_{\mathrm{MDV}}\right)$, 最大尿意時排尿筋コンプ ライアンス $\left(\mathrm{C}_{\mathrm{MDV}}\right)$, 最大尿道閉鎖圧 $(\mathrm{MUCP})$, 機能 的尿道長（FPL）及び尿流量曲線を含む臨木症状につ いて検討を行った。

\section{結 果}

1. 臨床症状 (Table 2)

$\mathrm{RH}+\mathrm{RT}$ 群 (24例) のらち18例（75\%）は尿失禁を 主訴としていた，尿失禁の多くは腹圧性尿失禁に加之 反射性尿失禁を有していた，頻尿を主訴とするものは 3 例（13\%）で，排尿困難は 2 例（8％）であった。 $\mathrm{RH}$ 群 (13例) では尿失禁, 頻尿, 排尿困難が各々 7 例 (54\%)，5 例 (38\%)， 1 例（8\%）であり， mRH 群 （7例）では各々 1 例 (14\%)，1 例， 1 例で残りの 4 例では明らかな排尿障害を認めなかった。 RT 群（9 例)では頻尿が 5 例 (56\%)，排尿障害なしが 4 例(44\%) であった，尿流量曲線は RH+RT 群及び RH 群では 9 例中 8 例で intermittent flow を示し腹圧型排尿ハ

Table 2 Chief complaint of patients

\begin{tabular}{lccll}
\hline & $\begin{array}{l}\text { Radical hysterectomy } \\
\text { with postoperative } \\
\text { radiotherapy }\end{array}$ & $\begin{array}{l}\text { Radical } \\
\text { hysterectomy }\end{array}$ & $\begin{array}{l}\text { Modified } \\
\text { radical } \\
\text { hysterectomy }\end{array}$ & $\begin{array}{l}\text { Radiotherapy } \\
\text { alone }\end{array}$ \\
\hline $\begin{array}{l}\text { Urinary } \\
\text { incontinence }\end{array}$ & $18(75 \%)$ & $7(54 \%)$ & $1(14 \%)$ & 0 \\
$\begin{array}{l}\text { Urinary } \\
\text { frequency }\end{array}$ & $3(13 \%)$ & $5(38 \%)$ & $1(14 \%)$ & $5(56 \%)$ \\
Dysuria & $2(8 \%)$ & $1(8 \%)$ & $1(14 \%)$ & 0 \\
None & 0 & 0 & $4(57 \%)$ & $4(44 \%)$ \\
\hline
\end{tabular}


Fig. 1 The bladder volume at maximum desire to void. The volume decreased after radiotherapy.

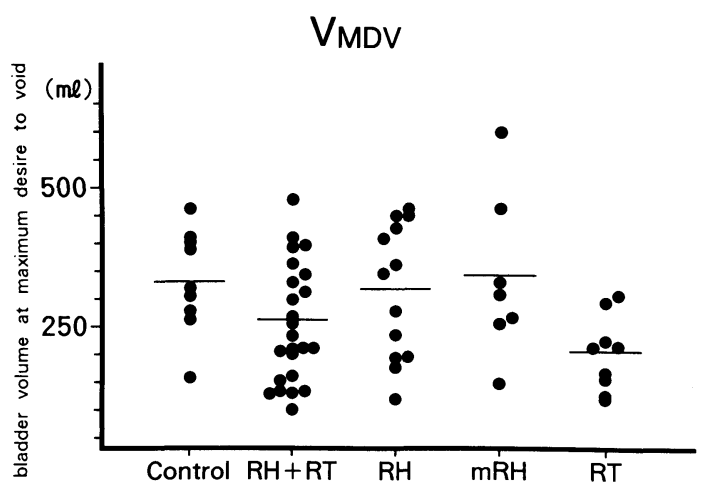

Fig. 2 The intravesical pressure at maximum desire to void. The pressure significantly increased after radical hysterectomy.

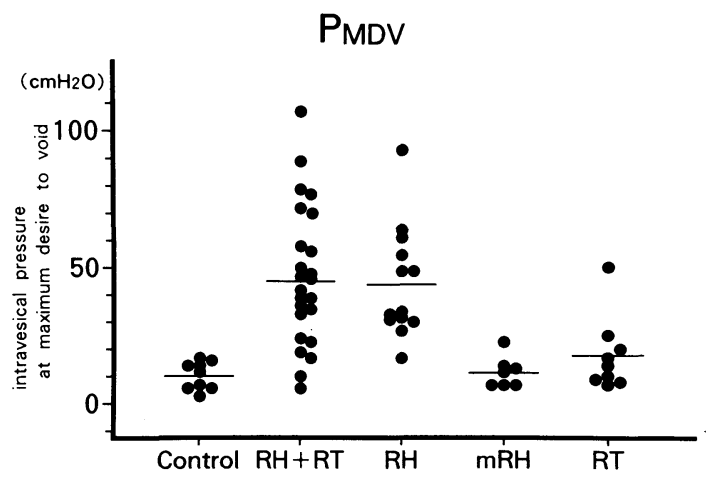

ターンであったが, mRT 群 3 例はすべて continuous flow を示した. $50 \mathrm{ml}$ 以上の残尿を有する症例は $\mathrm{RH}+$ $\mathrm{RT}$ 群で 3 例 (13\%), RH 群で 2 例 (15\%), RT 群で 1 例（11\%）であった。

2. 最大尿意時膀脱容量 $\left(\mathrm{V}_{\mathrm{MDV}}\right)$

$\mathrm{V}_{\mathrm{MDV}}$ は対照群では平均 $333 \mathrm{ml}$ であったが, $\mathrm{RT}$ 群で は平均 $203 \mathrm{ml}$ と有意に減少して括り $(\mathrm{p}<0.01), \mathrm{RH}+$ $\mathrm{RT}$ 群でも平均 $262 \mathrm{ml}$ とやや減少していた. $\mathrm{RH}$ 群, $\mathrm{mRH}$ 群では各々平均 $317 \mathrm{ml}, 340 \mathrm{ml}$ で対照群と比較し 差がなかった (Fig. 1).

3. 最大尿意時膀脱内圧 ( $\left.\mathrm{P}_{\mathrm{MDV}}\right)$

$\mathrm{P}_{\mathrm{MDV}}$ は対照群では平均 $10.6 \mathrm{cmH}_{2} \mathrm{O}$ で, 広汎子宮全 摘術後の $\mathrm{RH}+\mathrm{RT}$ 群及び $\mathrm{RH}$ 群では各々平均 45.2 $\mathrm{cmH}_{2} \mathrm{O}, 44.2 \mathrm{cmH}_{2} \mathrm{O}$ と有意に上昇していた $(\mathrm{p}<$ $0.01)$. 一方 $\mathrm{mRH}$ 群, $\mathrm{RT}$ 群では各々平均 $11.9 \mathrm{cmH}_{2}$ $\mathrm{O}, 17.8 \mathrm{cmH}_{2} \mathrm{O}$ で対照群と比較し差がなかった（Fig.
Fig. 3 The detrusor compliance at maximum desire to void. The compliance significantly decreased after radical hysterectomy and/or radiotherapy.

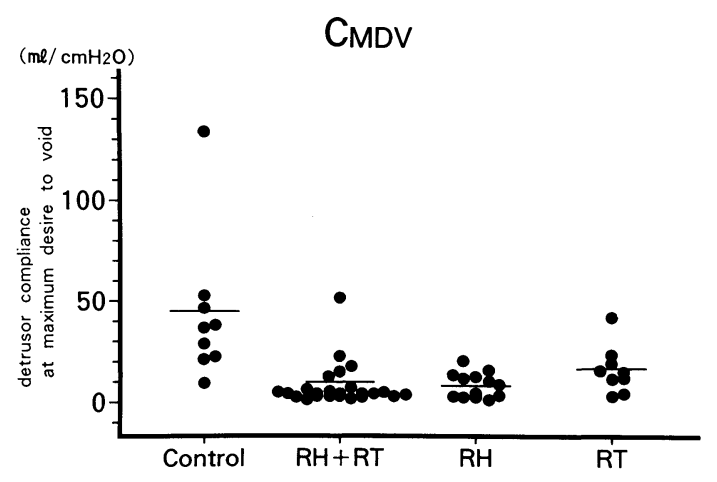

Fig. 4 The maximum urethral closure pressure. The pressure significantly decreased after radical hysterectomy.

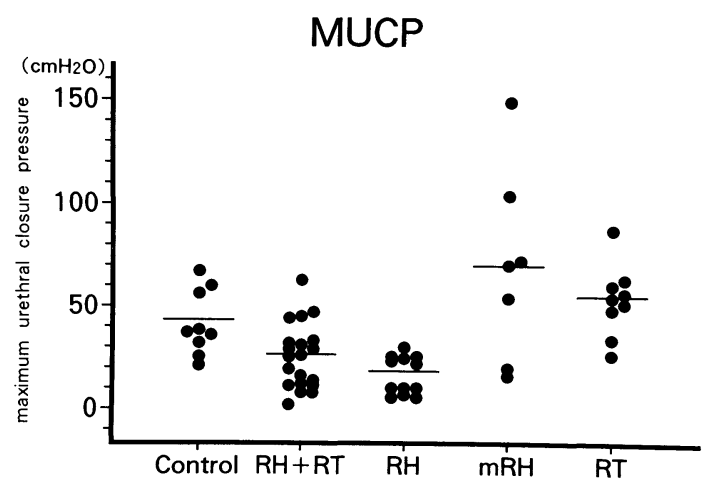

2).

4. 最大尿意時排尿筋コンプライアンス $\left(\mathrm{C}_{\mathrm{MDV}}\right)$

$\mathrm{C}_{\mathrm{MDV}}$ は対照群では平均 $43.8 \mathrm{ml} / \mathrm{cmH}_{2} \mathrm{O}$ であったが $\mathrm{RH}+\mathrm{RT}$ 群, $\mathrm{RH}$ 群, RT 群では有意に低下しており $(\mathrm{RH}+\mathrm{RT}$ 群 : $\mathrm{p}<0.01, \mathrm{RH}$ 群 : p $<0.01, \mathrm{RT}$ 群 : $\mathrm{p}<0.05)$, 各々平均 $10.4 \mathrm{ml} / \mathrm{cmH}_{2} \mathrm{O}, 9.3 \mathrm{ml} / \mathrm{cmH}_{2} \mathrm{O}$, $16.6 \mathrm{ml} / \mathrm{cmH}_{2} \mathrm{O}$ であった (Fig. 3).

5. 最大尿道閉鎖圧 (MUCP)

対照群では平均 $42.3 \mathrm{cmH}_{2} \mathrm{O}$ であったが, $\mathrm{RH}+\mathrm{RT}$ 群, $\mathrm{RH}$ 群では有意に低下しており $(\mathrm{RH}$ 群： $\mathrm{p}<0.05$, $\mathrm{RH}$ 群 : $\mathrm{p}<0.01$ ), 各々平均 $26.3 \mathrm{cmH}_{2} \mathrm{O}, 17.3 \mathrm{cmH}_{2} \mathrm{O}$ であった. $\mathrm{mRT}$ 群, $\mathrm{RT}$ 群では各々平均 $70.3 \mathrm{cmH}_{2} \mathrm{O}$, $54.2 \mathrm{cmH}_{2} \mathrm{O}$ と対照群と比較し差がなかった(Fig. 4).

6. 機能的尿道長 (FPL)

対照群では平均 $3.3 \mathrm{~cm}$ であったが, $\mathrm{RH}+\mathrm{RT}$ 群で 
Fig. 5 The functional profile length. The length shortened after radical hysterectomy with radiotherapy.
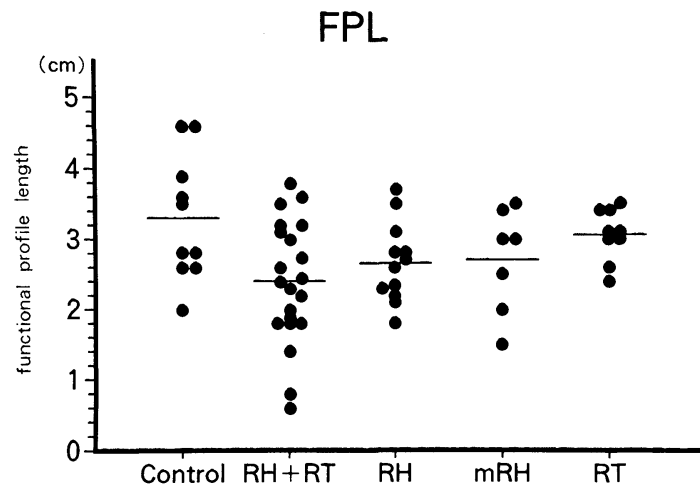

Fig. 6 The changes of urodynamic values in a patient underwent radical hysterectomy. The detrusor compliance and maximum urethral closure pressur decreased in 2 months after operation. The overactive detrusor function were seen after operation.

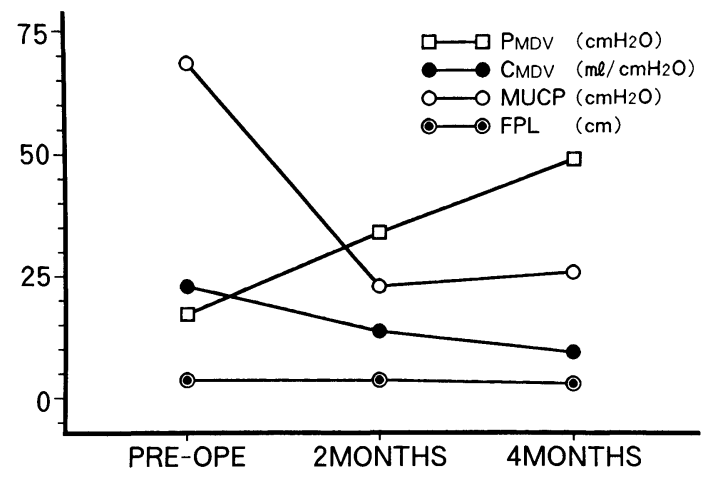

は平均 $2.4 \mathrm{~cm}$ と有意に短縮していた $(\mathrm{p}<0.05) . \mathrm{RH}$ 群, $\mathrm{mRH}$ 群, RT 群では各々平均 $2.7 \mathrm{~cm}, 2.7 \mathrm{~cm}, 3.1$ $\mathrm{cm}$ とやや短縮していた（Fig. 5).

Fig. 6 に広沉子宮全摘術前後に複数回の検査が施 行できた 24 歳の症例の術前, 術後 2 力月及び 4 カ月の $\mathrm{P}_{\mathrm{MDV}}, \mathrm{C}_{\mathrm{MDV}}, \mathrm{MUCP}, \mathrm{FPL}$ の変動を示した。術前には $\mathrm{V}_{\mathrm{MDV}}$ は $389 \mathrm{ml}, \mathrm{P}_{\mathrm{MDV}}$ は $17 \mathrm{cmH}_{2} \mathrm{O}, \mathrm{C}_{\mathrm{MDV}}$ は $22.9 \mathrm{ml} / \mathrm{cmH}_{2}$ O, MUCP は $68 \mathrm{~cm} \mathrm{H}_{2} \mathrm{O}, \mathrm{FPL}$ は $3.6 \mathrm{~cm}$ であったが, 術後 2 力月の CMG では蓄尿相での排尿筋過活動が認 められ $\mathrm{P}_{\mathrm{MDV}}$ は $34 \mathrm{cmH}_{2} \mathrm{O}$ に上昇し, その結果 $\mathrm{C}_{\mathrm{MDV}}$ は著 明に低下した。排尿筋過活動は 4 力月目においても持 続していた。 また MUCP も術後 2 カ月で $23 \mathrm{cmH}_{2} \mathrm{O}$ と 低下し，術後 4 カ月でも同様であった。一方 FPL は
徐々に短縮し 4 力月後には $3.1 \mathrm{~cm}$ となった。

\section{考察}

子宮癌根治術後の排尿障害については広く知られて いるが，術後一過性の排尿困難が軽快するとその後の 排尿障害は治療される事なく経過し，重篤な尿路合併 症により初めて泌尿器科を訪れることもまれではな い，しかし最近，患者の生活の質及び尿失禁に対する 注目が高まるにつれ，排尿障害で泌尿器科を受診する 患者が増加してきて打り, 子宮癌根治術後の膀胱尿道 機能障害に対する正確な評価が重要と考えられてい る.

我々は広沉及び準広沉子宮全摘術の膀胱尿道機能に 与える影響を放射線単独療法群及び対照群と比較し検 討し，いわゆる過緊張型膀胱を有する症例が多く，こ れらの変化は術後早期より認められることを明らかに した。従来，広汎子宮全摘術後の神経因性膀脱は核下 型神経因性膀胱として排尿筋収縮不全による排尿障害 や残尿による影響が重要視されてきた，排尿筋コンプ ライアンスの低下を認める原因についても膀脱内圧の 持続的上昇による器質的変化, 併用される放射線療法 による線維化，手術による神経損傷など一定の見解が 得られていない(6)7)．金子は ${ }^{1)}$ 子宮癌根治術後の神経因 性膀胱に打いて術直後を除き， $\mathrm{V}_{\mathrm{MDV}}$ の減少， $\mathrm{P}_{\mathrm{MDV}}$ の上 昇， $\mathrm{C}_{\mathrm{MDV}}$ の低下を報告し，これらの変化は神経損傷に よるものであるとしているが，我々の検討でも術後早 期より $\mathrm{P}_{\mathrm{MDV}}$ の上昇と $\mathrm{C}_{\mathrm{MDV}}$ の低下を認めた。一方, $\mathrm{V}_{\mathrm{MDV}}$ は子宮癌根治術のみでは減少しなかった。これら の症例の膀胱内圧曲線は初圧より腹満を訴えるまでは ほぼ正常な曲線であるがその後急激に内圧が上昇し排 尿筋の抑制なしにカテーテル周囲より勢い良く炭酸ガ スが漏出することが特徵で，放射線単独療法群にみら れる徐々に膀胱内圧の上昇する低コンプライアンス膀 脱とは異なり，排尿筋過活動の存在を示すものと考兄 られた。

骨盤神経叢損傷が排尿筋コンプライアンスの低下を 起こす機序について, Norlen ら ${ }^{8)}$ は骨盤神経及び下腹 神経の切断により，アドレナリン作動性神経の増加と $\alpha$-receptor 活性の増加により, 排尿筋コンプライアン スの低下が起こることを報告しているが，Neal ら 直腸癌術後の膀胱生検によりアドレナリン作動性神経 の増加は認められなかったとしており，いまだ一定の 見解は得られていない(10). 排尿筋に分布する自律神経 の多くは膀胱周囲や膀胱壁内の神経節に由来し，それ らの神経節は排尿筋の協調的弛緩及び収縮を制御して 
いるとされている ${ }^{1112)}$ 。広沉子宮全摘術による骨盤神 経叢の損傷が膀胼壁在神経節の除中枢化を引き起こす 事により，排尿筋コンプライアンスを低下させている 可能性も考兄られた。 また併用される放射線療法は $\mathrm{V}_{\mathrm{MDV}}$ を低下させることょり $\mathrm{C}_{\mathrm{MDV}}$ の低下をきたし，術 後排尿障害を増強するものと考兄られた。

尿道内圧測定では MUCP が広沉子宮全摘術後有意

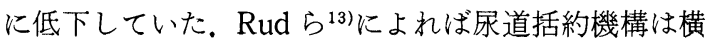
紋筋，平滑筋及び結合組織，血管床により構成されて いるとされている，子宮癌根治術によるMUCP の低 下の原因として骨盤神経叢より由来する交感神経損傷 による平滑筋収縮機能低下によるもの，根治術による 尿道血流障害等が考兄られた。また骨盤神経内に外尿 道括約筋を支配する体性神経が含まれているといら報 告もあり ${ }^{14)}$ ，骨盤神経叢内の体性神経損傷により MUCP が低下した可能性も考兄られる．FPLの短縮 が子宮癌根治術後及び放射線療法後の両者に認められ た。金子は子宮癌根治術後 1 年以上経過した症例に打 けるFPLの短縮を報告し，術後の間接的あるいは 2 次的変化であるとしている。放射線単独療法に打いて も FPL の短縮を認め, 子宮癌根治術及び放射線併用 療法では有意に短縮することより, 手術や放射線療法 による血行障害を含む尿道の器質的変化が原因の 1 つ ではないかと考兄られた。

広汎子宮全摘術後には汪とんどの症例に招いて尿意 の消失及び低下を認め，腹圧性及び反射性尿失禁を主 訴とするものは $68 \%$ ，特に放射線療法を併用された症 例では75\%と高率に認められた。従来より排尿困難に ついては多くの報告がなされて招り，我々の症例でも 尿流量測定が施行できた 9 例中 8 例の症例において腹 圧型排尿であったが, $50 \mathrm{ml}$ 以上の残尿を有する症例は 5 例 (14\%) と少なく, 補助的利尿筋（腹筇，横隔膜 など）の代償機能，尿道機能の低下により排尿障害は 軽減するものと考光られた。河村らの報告3)に打いて も約 $6 \sim 7$ 割に尿失禁を認めて扣り，今後子宮癌根治 術後の尿失禁に対する治療の重要性が増加するものと 考えられた。一方，骨盤神経叢を可能な限り温存した 準広汎子宮全摘術では対照群と比較し膀脱尿道機能に 差を認めなかった。術後排尿障害も $43 \%$ に認めるのみ で，排尿機能温存に対し有効な手術法であると考兄ら れた。

以上の尿流動態学的検討により子宮癌根治術後の尿 失禁に対しては抗コリン作用と $\alpha$ 交感神経刺激作用 を持つ塩酸イミプラミンを第一選択に治療している。
有効な症例が多い反面，子宮癌術後患者の多くに認め られる排便障害の悪化があり，投薬困難な症例も認め られている、治療については今後尿流動態学的検查を 含め一層の検討を行ら予定である。

\section{結語}

1. 広汎子宮全摘術後にはほとんぞの症例に和いて 尿意の消失及び低下を認め, 腹圧性及び反射性尿失禁 を主訴とするものが $68 \%$ ，特に放射線療法を併用され た症例では $75 \%$ と高率に認められた。一方排尿困難を 主訴とする者は $8 \%, 50 \mathrm{ml}$ 以上の残尿を有する症例も 5 例 (14\%) と少なく, 子宮癌術後神経因性膀脂に招 いては蓄尿障害に対する正確な評価と治療も重要であ ると考えられた。

2. 広汎及び準広汎子宮全摘術の膀胀機能に与兄る 影響を放射線単独療法群及び対照群と比較し検討し, 広沉子宮全摘術による神経損傷は $\mathrm{P}_{\mathrm{MDV}}$ の上昇と $\mathrm{C}_{\mathrm{MDV}}$ の低下をきたす事をあきらかにした。すた併用される 放射線療法は $\mathrm{V}_{\mathrm{MDV}}$ を低下させることより $\mathrm{C}_{\mathrm{MDV}}$ の低下 をきたし，術後排尿障害を増強するものと考兄られた。

3. 尿道内圧測定では MUCP が子宮癌根治手術後 有意に低下していた。また FPLの短縮が子宮癌根治 術後及び放射線療法後の両者に認められた。放射線単 独療法に打いてもFPLの短縮を認め, 子宮癌根治術 及び放射線併用療法では有意に短縮していた。

4. 骨盤神経叢を可能な限り温存した準広沉子宮全 摘術では対照群と比較し膀胱尿道機能に差を認めな かった。術後排尿障害も $43 \%$ に認めるのみで, 排尿機 能温存に対し有効な手術法であると考兄られた。

\section{文献}

1）金子茂男：排尿機構にかんする検討. 第11報。子宮 頸癌根治術後の神経因性膀脱。 その 1 . 排尿機能検 査に上る検討。日泌尿会誌，75，561-569，1984.

2）新川 徹, 岩坪暎二：婦人科手術に起因する神経 因性膀胱の経験。西日泌尿，38，364-368，1976.

3）河村伸吾, 三浦清變, 山辺 徹 : 子宮頸癌治療後の 排尿障害管理上の新しい問題点. 泌尿紀要, 21 , 223-226, 1975.

4) Woodside, J.R. and McGuire, E.J.: Detrusor hypertonicity as a late complication of a Wer. theim hysterectomy. J. Urol., 127, 1143-1145, 1982.

5) Twombly, G.H. and Landers, D.: The innervation of the bladder with reference to radical hysterectomy. Am. J. Obst. Gunec., 71, 1291-1300, 1956.

6) Krane, R.J. and Siroky, M.B.: Clinical Neuro- 
Urology, 2nd ed., p. 333, Little, Brown and Company, Boston, 1991.

7) Farquharson, D.I.M., Shingleton, H.M., Soong, S.J., Sanford, S.P., Levy, D.S., Hatch, K.D. and Hester, S.: The adverse effects of cervical cancer treatment on bladder function. Gynecol. Oncol., 27, 15-23, 1987.

8) Norlen, L., Dahlstrom, A., Sundin, T. and Svedmyr, N.: The adrenergic innervation and adrenergic receptor activity of the feline urinary bladder and urethra in the normal state and after hypogastric and/or parasympathetic denervation. Scand. J. Urol. Nephrol., 10, 177-184, 1976.

9) Neal, D.E., Bogue, P.R. and Williams, R.E. : Histological appearances of the nerves of the bladder in patients with denervation of the bladder after excision of the rectum. Brit. J. Urol., 54, 658-666, 1982.

10) Yokoyama, O., Nagano, K., Kawaguchi, K., Komatsu, K., Egawa, M. and Hisazumi, H. :
The influence of pelvic nerve transection on the neuromuscular system of the canine urinary bladder. Urol. Res., 20, 45-48, 1992.

11) Dixon, J.S., Gilpin, S.A., Gilpin, C.J., et al.: Intramural ganglia of the human urinary bladder. J. Urol., 55, 195-198, 1983.

12) Elbadawi, A. and Schenk, E.A.: A new theory of the innervation of bladder musculature. Part 1. Morphology of the intrinsic vesical innervation apparatus. J. Urol., 99, 585-587, 1968.

13) Rud, T., Andersson, K.E., Asmussen, M., Hunting, A. and Ulmsten, U.: Facters maintaining the intraurethral pressure in women. Invest. Urol., 17, 343-347, 1980.

14) Morita, T., Nishizawa, O., Noto, H. and Tsuchida, S.: Pelvic nerve innervation of the external sphincter of urethra as suggested by urodynamic horse-radish paroxidase studies. J. Urol., 131, 591-595, 1984.

（1992年10月 9 日受理） 